\title{
WAKAF SEBAGAI INSTRUMEN KEBIJAKAN PEMERINTAH UNTUK MENGATASI EKSTERNALITAS BARANG PUBLIK (PERSPEKTIF MAQASHID SYARI'AH)
}

\author{
Figuri Sancoyowati \\ Dewan Pengawas Syariah \\ Kanindo Jawa Timur
}

\begin{abstract}
Economic development bring externalities as a consequence of an economic activity in positive and negative side. An externality has beencaused by public goods whichis a goods that consumed by individual and will not effect to other in consumption of it. The issue of public goods is about a freeryder which caused in efficiency in government expenditures. Wakaf as a financial instument in Islam could bean alternatif to gainnationalin come that can solvean externality of public goods.
\end{abstract}

Key Words: wakaf, externalities, public goods, maqashid syari'ah

\section{PENDAHULUAN}

Pembangunan ekonomi hampir di setiap negara baik negara maju maupun negara berkembang pada umumnya bertumpu pada sumber daya alam dan produktivitas sistem alam atau lingkungan. Proses pembangunan ini ditandai dengan pemanfaatan sumber daya,yaitu segala sesuatu yang dapat menghasilkan barang dan jasa untuk kegiatan konsumsidimana hal ini akan membawa dampak (eksternalitas) positif dan negatif.

Eksternalitas positifnya dapat meningkatkan taraf hidup dan kesejahteraan masyarakatyang merupakan modal untuk tahap pembangunan berikutnya. Eksternalitas negatifnya, proses produksi dan konsumsi berpotensimenimbulkan pencemaran lingkungan. Eksternalitasnegatif ini sebagian dapat diatasi dengan penggunaan berbagai teknologi pencegah pencemaran lingkungan. Sedangkan eksternalitaslain yang mendasar terhadap struktur ekosistem merupakan gangguan yang tidak mungkin diatasi oleh kemampuan manusia. Gangguan seperti ini harus dihindarkan sebab apabila tidak, hal itu merupakan gangguan terhadap kelangsungan hidup manusia dan makhluk lain.

Eksternalitas adalah kerugian atau keuntungan yang diderita atau dinikmati pelaku ekonomi karena tindakan pelaku ekonomi lain yang tidak tercermin dalam harga pasar. Sedangkan efisiensi pasar adalah suatu keadaan apabila suatu pasar sudah dapat mengalokasikan seluruh sumber-sumber daya yang pada umumnya secara efisien.

Eksternalitas timbul pada dasarnya karena aktivitas manusia yang tidak mengikuti prinsipprinsip ekonomi yang berwawasan lingkungan. Dalam pandangan ekonomi, eksternalitas dan ketidakefisienan timbul karena salah satu atau lebih dari prinsip-prinsip alokasi sumber daya yang efisien tidak terpenuhi. Karakteristik barang atau sumber daya publik, sumber daya bersama, ketidaksempurnaan pasar, kegagalan pemerintah merupakan keadaan-keadaan dimana unsur hak pemilikan atau pengusahaan sumber daya (propertyrights) tidak terpenuhi. Sejauh semua faktor ini tidak ditangani dengan baik, maka eksternalitas dan ketidakefisienan ini tidak bisa dihindari. Kalau ini dibiarkan, maka ini akan memberikan dampak yang tidak menguntungkan terhadap ekonomi terutama dalam jangka panjang.

\section{Eksternalitas dalam Perspektif Maqashid Syari’ah}

Dalam perspektif Islam, semua aktivitas manusia harus sejalan dengan maqashidsyari'ah (tujuan Islam) dimana menurut istilah, asy-Syatibi menyatakan,

\section{"Sesungguhnya syariah bertujuan untuk mewujudkan kemaslahatan manusia di dunia dan di akhirat"}

Dari pengertian tersebut dapat dikatakan bahwa tujuan syariah menurut asy-Syatibi adalah kemaslahatan umat manusia. Lebih jauh, ia menyatakan bahwa tidak satu pun hukum Allah Swt yang tidak mempunyai tujuan karena hukum yang tidak mempunyai tujuan sama dengan membebankan sesuatu yang tidak dapat dilaksanakan. Kemaslahatan dalam hal ini diartikannya sebagai segala 
sesuatu yang menyangkut rezeki manusia, pemenuhan penghidupan manusia dan perolehan apa-apa yang dituntut oleh kualitas emosional dan intelektualnya dalam pengertian yang mutlak.

Dengan demikian, kewajiban-kewajiban dalam syariah menyangkut perlindungan maqashidalsyariahyang ada pada gilirannya bertujuan untuk melindungi kemaslahatan manusia. Asy-Syatibi menjelaskan bahwa syariah berurusan dengan perlindungan mashalih, baik dengan cara yang positif seperti demi menjaga eksistensi mashalih, syariah mengambil berbagai tindakan untuk menunjang landasan-landasan mashalih; maupun dengan cara preventif, seperti syariah mengambil berbagai tindakan untuk melenyapkan unsur apapun yang secara aktual dan potensial merusakmashalih.

Mukhlis (2009) menjelaskan bahwa pembangunan berkelanjutan yang terdiri dari kelestarian lingkungan (environmentalsustainability), keberlangsungan ekonomi (economicsustainability), kelestarian sosial (socialsustainability) dan pembangunan berkelanjutan (sustainabledevelopment) akan dapat terjadi apabila pemerintah mampu meminimalisir eksternalitas negatif atas pengelolaan barang publik.

Menurut asy-Syatibi, kemaslahatan dapat terealisasi apabila lima unsur pokok kehidupan manusia dapat diwujudkan dan dipelihara, yaitu agama, jiwa, akal, keturunan dan harta. Dengan kata lain, eksternalitas negatif atas pengelolaan barang publik tidak akan terjadi apabila tujuan pengelolaannya sejalan dengan maqashidsyari'ah.

\section{Wakaf dan Eksternalitas Barang Publik}

Diantara faktor penyebab terjadinya eksternalitas adalah karena (i) keberadaan barang publik (publicgoods), dimana barang publik adalah barang yang apabila dikonsumsi oleh individu tertentu tidak akan mengurangi konsumsi orang lain akan barang tersebut,(ii) Sumber Daya Bersama (SDB), dimana keberadaan sumber daya bersama (commonresources) atau akses terbuka terhadap sumber daya tertentu ini tidak jauh berbeda dengan keberadaan barang publik diatas.Sumber-sumber daya milik bersama, sama halnya dengan barang-barang publik, tidak ekskludabel dimana konsumsi suatu barang tidak dapat dibatasi hanya pada mereka yang memenuhi persyaratan tertentu. Sumber-sumber daya ini terbuka bagi siapa saja yang ingin memanfaatkannya, dan cuma-cuma. Namun tidak seperti barang publik, sumber daya milik bersama memiliki sifat persaingan. Pemanfaatannya oleh seseorang, akan mengurangi peluang bagi orang lain untuk melakukan hal yang sama. Jadi, dengan keberadaan sumber daya milik bersama ini, pemerintah juga perlu mempertimbangkan seberapa banyak pemanfaatannya yang efisien.

\section{FRAMEWORK}

WAKAF DALAM MENGATASI EKSTERNALITAS BARANG PUBLIK (PERSPEKTIF MAQASHID SYARI'AH)

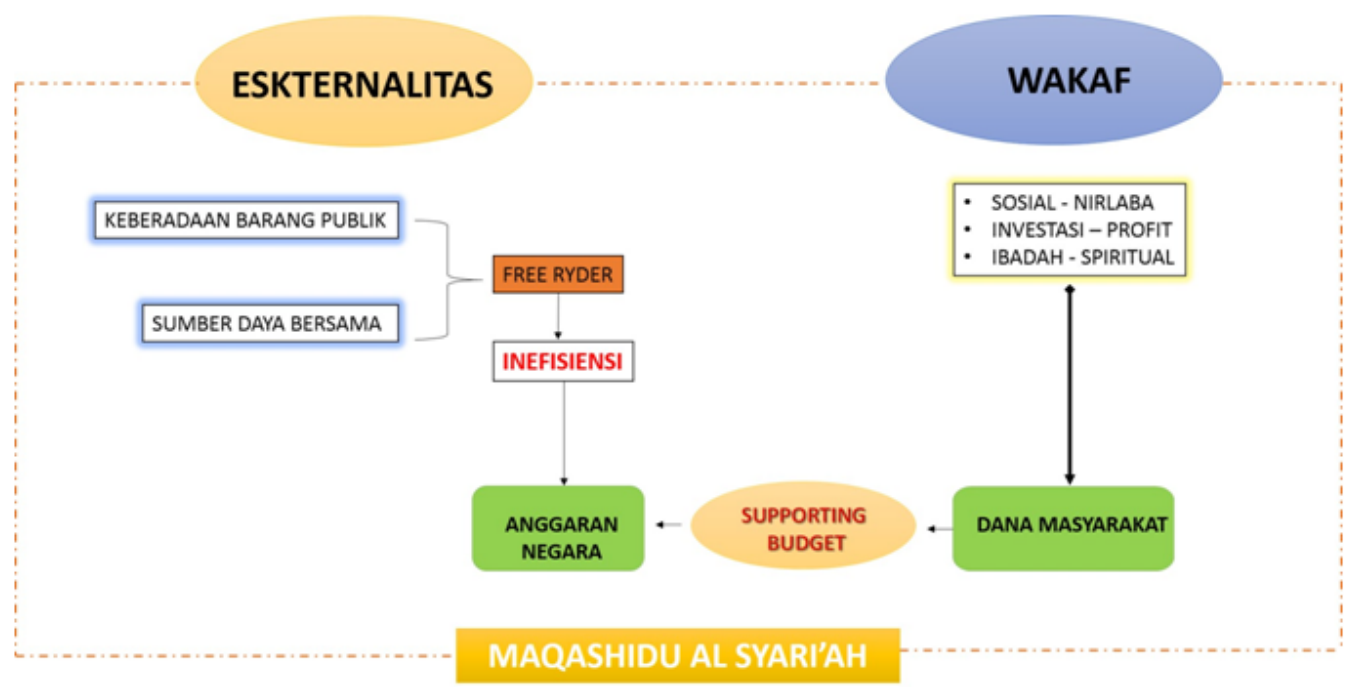


Permasalahan yang timbul dari barang publik ini yaitu adanya freerider (penumpang gratisataupengendara bebas) yaitu seseorang yang mengkonsumsi sumber daya tanpa membayar atau tidak membayar secara penuhatau kurang. Salah satu contohnya yaitu, seseorang yang tidak membayar pajak, padahal dengan membayar pajak berarti yang bersangkutan ikut membantu membayar untuk barang-barang publik. Karena semua warga negara mendapatkan keuntungan dari fasilitas, seperti jalan, pabrik pengolahan air dan fasilitas umum lainnya. Oleh karenanya anggaran belanja pemerintah menjadi tidak efisien. Dana yang seharusnya dialokasikan ke sektor lain seperti untuk program pengentasan kemiskinan dan peningkatan kesehatan masyarakat pada akhirnya terserap untuk memenuhi barang publik dan sumber daya bersama karenanya sumber pendapatan negara menjadi berkurang. Padahal infantmortalityyang tinggi dan healthexpenditureyang rendah mengindikasikan bahwa pemerintah tidak mampu untuk secara totalmelaksanakan pembangunan.

Berdasarkan publikasi statistik berkaitan dengan Key Socio-EconomicStatisticyang dikeluarkan oleh Islamic Development Bank (IDB) tahun 2015 menunjukan bahwa kondisi sosioekonomi negara-negara anggota Organization Islamic Conference $(O I C)$ atau dalam bahasa Indonesia OKI masih jauh berbeda dan cukup memprihatinkan apabila dibandingkan dengan negara-negara maju lainnya. Dalam publikasinya, terdapat 3 poin yang dijadikan sandaran utama dalam menganalisis kondisi sosio-ekonomi, yakni: (1) indikator demografi dan pembangunan manusia, (2) indikator makroekonomi, (3) indikator ekonomi sektor eksternal(DEKS BI-DES FEB Unair: 2016)

Lebih lanjut dalam publikasi tersebut dijelaskan bahwa berdasarkan penjelasan ketiga indikator tersebut, indikator sosio-ekonomi yang paling tepat untuk menggambarkan kondisi kemiskinan dan peningkatan kesejahteraan masyarakat di suatu negara ialah indikator demografi dan pembangunan manusia. Berkaitan dengan indikator tersebut, populasi anggota OIC pada tahun 2013 meningkat sebesar 1,9\% dengan dependencyratioyang cukup besar yaitu sekitar 62,3\%. Dengan kondisi ini penting untuk memperhatikan indikator kesehatan sebagai salah satu ukuran guna menentukan produktivitas bagi usia produktif di negara-negara anggota OIC. Di antara data yang penting di bidang kesehatan adalah infanmortalityratedan lifeexpectancyatbirthrate.

Grafik 1.1 Tingkat Kematian Bayi per 1000 Kematian

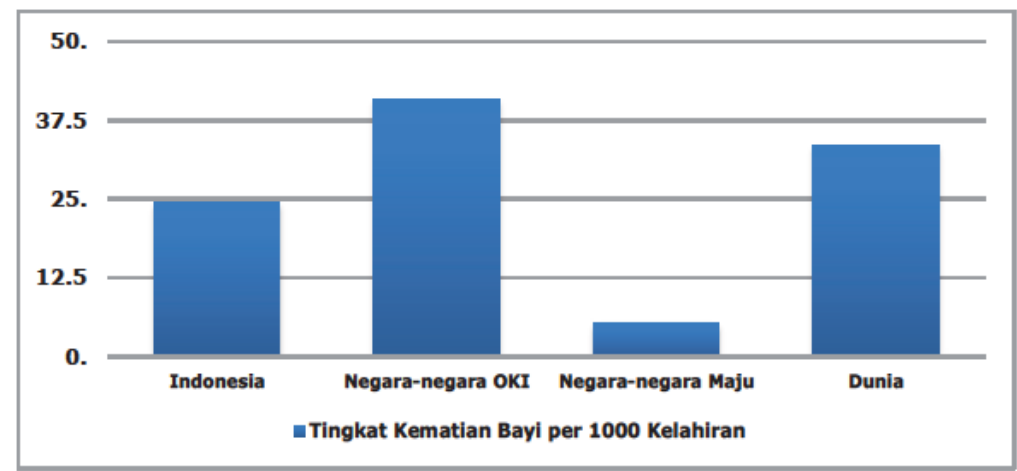

Sumber: Economic Research and Policy Department. 2015. Key Socio-Economic Statistics on IDB Member Countries, Jeddah: Islamic Development Bank, hlm. 17

Grafik 1.2 Angka Harapan Hidup per Tahun

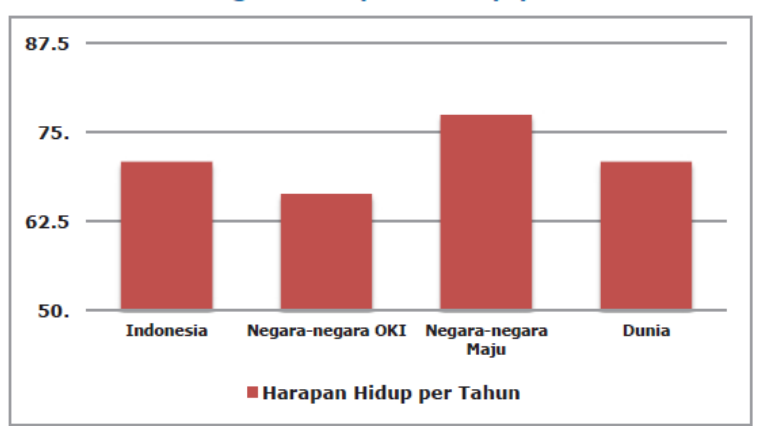

Sumber: Economic Research and Policy Department. 2015. Key Socio-Economic Statistics on IDB Member Countries, Jeddah: Islamic Development Bank, hlm. 23 


\section{Grafik 1.3 Grafik Perbandingan kemiskinan terbanyak dan GDP tertinggi dalam OKI}
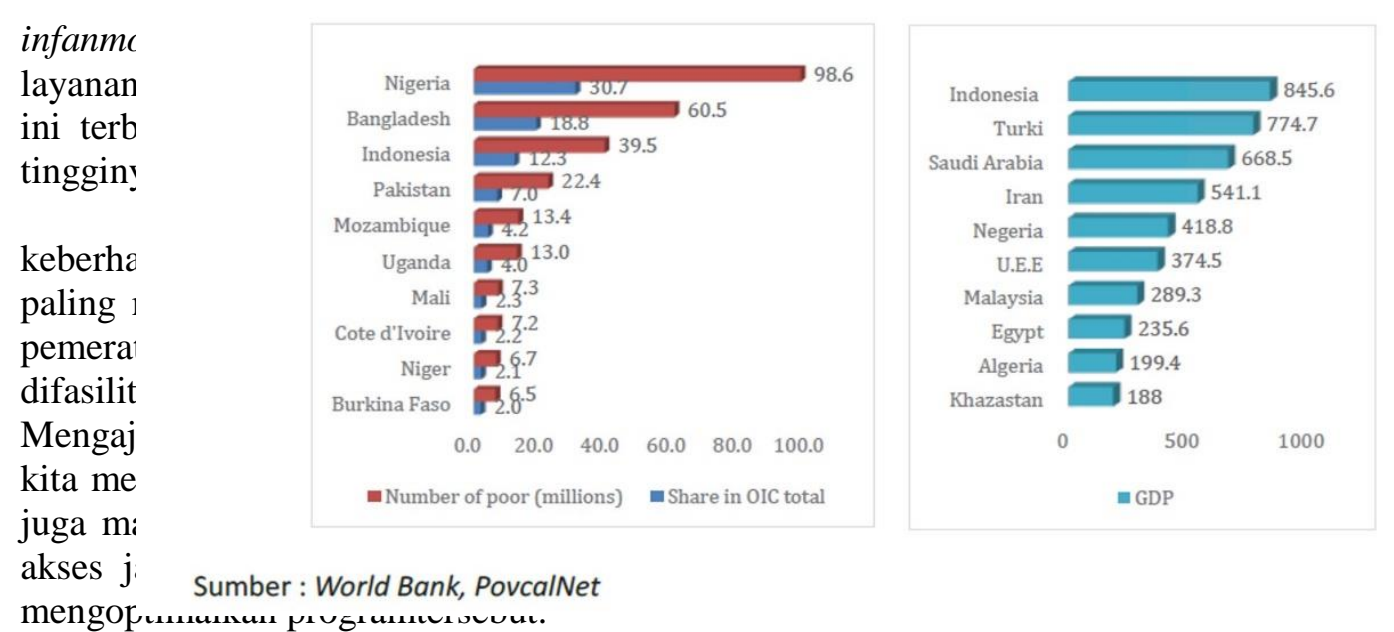

linya

rnatif

a hal

nasih

kator

yang

nulai

baik

nesia

abila

likan

serta

dan

Seperti halnya dengan tingkat kesehatan, masih minimnya tingkat pendidikan masyarakat ini disebabkan oleh kurangnya dana untuk membackupprogram-program pemerintah untuk mengatasi hal tersebut. Apabila kita melihat kondisi keuangan negara dimana posisi hutang negara jauh dibawah potensi penerimaan penerimaan negara, maka hal ini menjadi wajar. Namun, bukan berarti kondisi ini dapat kita biarkan saja dan tidak dicarikan solusinya. Karena jika dibiarkan, maka kita harus menunggu beberapa dekade untuk terlepas dari hutang yang sekarang dan melakukan pembangunan secara optimal.

Ekonomi Islam telah memiliki alternatif jenis instrumen yang dapat mengatasi hal tersebut. Instrumen tersebut adalah wakaf. Wakaf merupakan sedekahdari individual yang pokoknya tidak boleh habis. Gabungan danasosialdari invidu-individu yangkaya inidapatdigunakanuntuk mendirikan rumah sakit wakaf atau mendirikan sekolah dengansegala perlengkapannya.

Instrumen wakaf ini adalah sebuah elemen filantropi yang secara ruh, spirit, sesuai dengan fitrah manusia yang disebut Asutay sebagai homo IslamicusdimanaAsutay (2007) dalam Mahyudi (2015) menyebutkan ciri-cirinya sebagai berikut:

"socially concerned God-conscious individuals who (a) in seeking their interests are similarly concerned with the social good, (b) conducting economic activity in a rational way in accord an cewith the Islamic constra intsregarding social environment and here after; and (c) in trying to maximise his/herutility seeks to maximise social welf are as well by taking into account the here after."

Lebih lanjut Asutay menjelaskan,

"This is principallydue to "homos islamicus", who knows tha the lives on this earth, not toobey his Nafs, butto controlit."

Secara sederhana, wakaf dapat dimanfaatkan untuk kepentingan yang bersifat komersial maupun nirlaba. Umumnya, wakaf dipahami sebagai penyedia infrastruktur bagi aktivitas-aktivitas nirlaba religius, seperti pembangunan masjid, madrasah dan pemakaman. Pada kenyataannya, wakaf dapat dikelola sebagai investasi yang bersifat komersial.

Wakaf yang ditujukan bagi sektor nirlaba akanberperan dalam operasional sektor nirlaba tersebut. Misalkan, lahan wakaf yang dibangununtuk pesantren akan berperan dalam operasional pendidikan Islam yang dijalankan pesantren. Apabila lahan wakaf dibangununtukrumah sakit bagi dhuafa, maka wakaf berperan dalam operasional layanan kesehatan yang dijalankan rumah sakit tersebut.

Wakaf dapat pula diinvestasikan pada sektor komersial dan infrastrukturyang dapat menghasilkan laba. Misalkan, untukpembangunangedungperkantoran yang memiliki unit-unit yang 
dapat disewakan. Laba yang dihasilkan dari penyewaan unit kantor dapat digunakan untuk mendukung operasional sektor nirlaba, misalkan untuk beasiswa para santri di pesantren atau bantuan bea premi BPJS bagi pasien di rumah sakit bagi dhuafa. Padaakhirnya, apabila hal tersebut dapat dijalankan maka akan dapat memberikanmanfaat fiskal. Maksudnya adalah, layanan publik yang biasanya didapatkandari pemerintah, seperti pembangunan infrastruktur dan layanan sosial,dapat dijalankan oleh masyarakat melalui wakaf. Hal ini tentu saja baik bagianggaran negara karena belanja pemerintah telah disubstitusi oleh aktivitas filantropi berupa wakaf (DEKS BI-DES FEB Unair: 2016)

Terdapat beberapa penelitian yang membahas hal ini, diantaranya Medias (2010) yang menerangkan bahwa sebagai negara yang berpenduduk mayoritas muslim, eksistensi wakaf memiliki prospek yang baik dan akan sangat diterima oleh masyarakat Indonesia sehingga wakaf uang diperkirakan akan memberikan kontribusi besar bagi percepatan pembangunan di Indonesia. Bahkan dimungkinkan, wakaf uang bisa menjadi jalan alternatif untuk melepas ketergantungan bangsa ini dari lembaga-lembaga kreditor multilateral sekaligus menstimulasi pertumbuhan ekonomi Indonesia khususnya ekonomi Islam..

Kasdi (2014) menerangkan bahwa model pengelolaan dan pemanfaatan dana wakaf yang ada di Indonesia dilakukan di beragam sektor seperti kesehatan, businesscenter, pendidikan, sarana ibadah bahkan untuk investasi melalui sektor kredit mikro, sektor portofolio keuangan syari'ah, dan sektor investasi langsung. Kasdi lebih lanjut menyebutkan bahwa sebagian besar lembaga sosial yang berdiri saat ini dananya ditopang dari wakaf dan bergerak dalam bidang pengelolaan wakaf secara produktif dalam rangka memberikan pembinaan dan perlindungan kepada masyarakat, seperti yayasan yatim piatu, lembaga perlindungan anak-anak, lembaga pendidikan, lembaga kesehatan, penyaluran air bersih ke seluruh kota dan berbagai kegiatan sosial lainnya.

Penelitian lain yang dilakukan DEKS BI bekerjasama dengan DES FEB UNAIR (2016) memaparkan pengelolaan dana wakaf di beberapa negara diantaranya di Saudi Arabia. Adapun beberapa pelaksanaan pengelolaan dan pengembanganwakaf dalam berbagai bentuknya sebagai beirkut: 1) Perluasan masjid al-Haram dan masjid al-Nabawi dan masjid-masjid lainnya; 2) Fasilitas jalan umum seperti tol dari Jeddah ke Makkah dan Jembatan al-Mina serta masih banyak lainnya; 3) Fasilitas pemondokan dan saranan pendukung untuk jamaah haji; 4) Penerbitan dan percetakan mushaf al-Qur'an dan membagikannya secara gratis ke berbagai belahan negara; 5) Berbagai pusat kajian dakwah, seperti di Argentina dan Spanyol, berbagai lembaga pendidikan di Amerika, London, Albania, danMoskow serta pusat kajian Islam seperti di Harvard University dan London; 6) Pengembangan saham, pertokoan dan perhotelan di Madinah.

Sedangkan di Turki, selain wakaf berbentuk properti, fasilitas kesehatan dan pemberian beasiswa, menurut Rozalinda (2015: 385), Direktorat Wakaf Turki juga mengelola sejumlah aset wakaf berbentuk investasi sebagai berikut: AyvalikandAydenOlive Oil Corp, TasdelenHealthy Water Corp,Taksim Hotel Sheraton, GurabaHospital, Turkis IS Bank, Aydir Textile Industry Sea Copper Industry ConstructionandExport/ Import Corp, TurkishAwqaf Bank, Waqf Bank \& Finance Corporation, sebuah perusahaan yang bertugas memobilisasi sumber-sumber wakaf dan menjadi sumber pembiayaanproyek wakaf di negara Turki.

\section{PENUTUP}

Dari pemaparan penelitian tentang wakaf di atas dapat ditarik kesimpulan bahwa wakaf merupakan instrumen filantropi yang sangat fleksibel dan dapat dioptimalkan pengelolaannya untuk menyediakan segala fasilitas publik bahkan lebih lanjut dapat mengentaskan kemiskinan melalui berbagai program pemberdayaan ekonomi masyarakat. Wakaf juga dapat dijadikan sumber pendapatan negara non pajak yang secara potensi lebih besar dibandingkan potensi dari pajak itu sendiri.

Apabila ditinjau secara lebih terperinci, peran wakaf dalam memberikan berbagai manfaat seperti dipaparkan dalam penelitian-penelitian di atas dapat terjadi melalui pengelolaan wakaf yangdilakukan secara baik. Sebagai instrumen keuangan Islam maka pengelolaan wakaf harus sesuai dengan tujuan yang sudah diatur oleh Islam melalui Al Qur'an dan hadits yang lebih dikenal dengan maqashidsyariah. Pengelolaan wakaf secara baik akan dapatmendorong peran wakaf sebagai instrumenpembangunan negara. 


\section{DAFTAR PUSTAKA}

Amalia, Euis. 2010. Sejarah Pemikiran Ekonomi Islam; Dari Masa Klasik Hingga Kontemporer.GramataPublishing. Depok

Bank Indonesia. 2016. Wakaf: Pengaturan dan Tata Kelola yang Efektif. Departemen Ekonomi dan Keuangan Syariah - Bank Indonesia. Departemen Ekonomi Syariah Fakultas Ekonomi dan Bisnis - Universitas Airlangga

Karim, AA. 2006. Sejarah Pemikiran Ekonomi Islam. Raja Grafindo Persada. Jakarta

Kasdi, Abdurrahman. 2014. Model Pemberdayaan Wakaf Produktif di Indonesia. ZISWAF, Vol. 1, No. 1, Juni 2014

Mahyudi, Mohd. 2015. 'True Man': The True Economic Man for Islamic Economics.GJAT Vol 5 Issue 2-67 Desember 2015. ISSN : 2232-0474. E-ISSN : 2232-0482. www.gjat.my

Mauleny, Ariesy Tri. 2015. Aglomerasi, Perubahan Sosial Ekonomi, dan Kebijakan Pembangunan Jakarta. Jurnal Ekonomi \& Kebijakan Publik, Vol. 6, No. 2, Desember 2015147 - 162

Medias, Fahmi. 2010. Wakaf Produktif Dalam Perspektif Ekonomi Islam. Junal Ekonomi IslaLa-Riba, Vol. IV No. 1 Juli 2010

Mukhlis, Imam. 2009. Eksternalitas, Pertumbuhan Ekonomi dan Pembangunan Berkelanjutan dalam Perspektif Teoritis. Jurnal Ekonomi Bisnis Tahun 14 |No. 3| Nopember 2009

Munir, Zainul A. 2013. Revitalisasi Manajemen Wakaf Sebagai Penggerak Ekonomi Masyarakat.deJure, Jurnal Syariah dan Hukum, Volume 5 Nomor 2, Desember 2013, hlm. $162-171$

Rahman, Asma, Ab. 2009. Peranan Wakaf Dalam Pembangunan Ekonomi Umat Islam Dan Aplikasinya Di Malaysia.ShariahJournal, Vol. 17, No. 1 (2009) 113-152

Rahmadhani\&Herianingrum. 2016; Dampak Eksternalitas Positif PT.PETROKIMIA Gresik Terhadap Masyarakat Dalam Perspektif Maqashid. Jurnal Ekonomi Syariah Teori dan Terapan Vol. 3 No. 10 Oktober 2016: 782-799

Retnandari, Nunuk D. 2014. Pengantar Ilmu Ekonomi Dalam Kebijakan Publik. Pustaka Pelajar. Yogyakarta

Sutarjo. 2016. Eksternalitas Pedagang Kaki Lima. Jurnal AdBispreneur Vol. 1, No. 1, April 2016 Hal. $1-8$

Wahid, Abdurrahman. 2001. Menggerakkan Tradisi: Esai-Esai Pesantren. PT. LKIS Pelangi Aksara. Jakarta

https://www.google.co.id/amp/s/dianmiracle.wordpress.com/2011/03/10/barang-publik-daneksternalitas/amp/

http://encyptc.blogspot.co.id/2012/10/barang-publik-dan-eksternalitas.html?m=1

http://uciandriya.blogspot.co.id/2012/04/barang-publik-eksternalitas.html?m=1

http://smkyaditamaoke.blogspot.co.id/2011/10/barang-publik-dan eksternalitas.html?m=1

www.qamaruddinshadie.com/2012/04/maqashid-shariah-maslahah-sebagai_29.html?m=1 